\title{
Rural Financing as a Panacea for Poverty Alleviation: A Study of Selected Micro and Small Enterprises in Ogun State
}

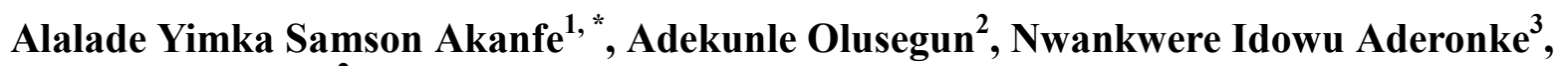 \\ Ogunsola Modupe ${ }^{2}$ \\ ${ }^{1}$ Department of Banking and Finance, School of Management Sciences, Babcock University, Ilishan-Remo, Nigeria \\ ${ }^{2}$ Department of Business Administration, Gateway Polytechnic, Saapade, Nigeria \\ ${ }^{3}$ Department of Business Administration and Marketing, School of Management Sciences, Babcock University, Ilishan-Remo, Nigeria
}

Email address:

alalades@babcock.edu.ng (A. Y. S. Akanfe)

${ }^{*}$ Corresponding author

\section{To cite this article:}

Alalade Yimka Samson Akanfe, Adekunle Olusegun, Nwankwere Idowu Aderonke, Ogunsola Modupe. Rural Financing as a Panacea for Poverty Alleviation: A Study of Selected Micro and Small Enterprises in Ogun State. Journal of Business and Economic Development. Vol. 4, No. 3, 2019, pp. 81-89. doi: 10.11648/j.jbed.20190403.12

Received: July 24, 2019; Accepted: August 24, 2019; Published: September 9, 2019

\begin{abstract}
Economic reforms have been implemented in Nigeria since 1980s which essentially entailed the shift from an administratively managed and public sector led economy to a market oriented and private sector led economy. Financial sector reforms were part of these broader economic reforms. A successful financial sector reform was expected to generate a dynamic process involving substantial changes in the country's real activities of production, exchange (trade) and finance. Sustainability of the reforms was expected to result in financial deepening, increase in the range of financial products in order to better serve the needs of the economy and enhance transformation of the economy (urban as well as rural) so that production, exchange and other economic activities take place in different ways and in the context of new or reformed institutions. However the progress being made as a result of financial sector reform, financial services to the rural population have been slow to develop. The financial sector reforms are still in progress, but there is increasing concern that the majority of the rural population which constitutes $70-80 \%$ of the population and comprise $90 \%$ of all the poor in Nigeria have not benefited from the financial reforms. They have largely been bypassed by these reforms. The need to enhance accessibility of financial services to the rural poor in Nigeria deserves high priority on the agenda of the on-going financial sector reforms. In recognition of the need for improving access to financial services by the rural population, this paper will address the experience and lessons learned to date in the development of rural finance with a view to facilitating appropriate design of rural finance and develop sustainable financial services for the needs of rural population in Nigeria, in order to reduce the increasing rate of poverty. The survey research design was adopted and data collected through questionnaires. The impact of rural financing as a panacea for poverty reduction in Nigeria was analyzed using the OLS regression method. The study revealed the existence of positive relationship between rural financing and poverty reduction in Nigeria. The study recommended that adequate measure must put in place to continue encouragement of rural financing in Nigeria.
\end{abstract}

Keywords: Financing, Poverty Reduction, Financial Services, Credit Facilities, Financial Sector Reforms

\section{Introduction}

The important role played by credit in financial leverage and poverty reduction was realized early in the history of Nigeria. This realization has made governments at all levels to reach the poor with one form of credit or the other, through the numerous credit and agricultural policies [6]. In spite of all these efforts however aimed at poverty reduction, poverty level index according to the National Bureau for Statistics (NBS) has remained high especially in the rural areas [25, 30]. According to the Bureau, in 1960, about $15 \%$ of 
Nigerians were poor.

By 1996 , poverty incidence in the country was $66 \%$ or 77 million Nigerians out of a population of 110 million were poor. Today, it is estimated that $54 \%$ of Nigerians are poor out of a population of 140 million or 75.60 million people are poor and this is in spite of the fact that since independence in 1960 that Nigeria has embarked on several poverty alleviation measures and similarly said to have earned a lot of revenue from the sale of oil and gas from among other sources [29].

In Nigeria, credit has been recognized as an essential tool for promoting micro and small enterprises (MSEs), as about 70 per cent of the population are engaged in the informal sector or in agricultural production. The Federal and State Governments in Nigeria have recognized that to enhance sustainable growth and development, the financial empowerment of the rural areas is vital, as rural area constitute the repository of the predominantly poor people/masses in society and in particular the MSE's. If this growth strategy is adopted and the latent entrepreneurial capabilities of this large segment of the people is sufficiently stimulated and sustained, then positive multipliers will and could be felt throughout the economy. To give effect to these aspirations, various policies have been instituted over time by the Federal Government of Nigeria to improve rural enterprise production capabilities, positively channel the potential of MSEs to enhance standards of living in the rural communities and to put the rural sector in the front burner of the government's development strategy [33].

Rural financing that leads to the transformation of individuals is all about improving living standards of the farmers, the artisans, the tenants and the landless within the simple and rustic economies of the country-sides and urban slums. The basis for employment generation and entrepreneurship development in rural areas, therefore, is to enhance the improvement of the living condition of the people. The micro and small scale entrepreneurs in rural areas lack the access to necessary financial facilities, especially credit from the commercial banks; this is because they are considered as not creditworthy [23].

The result was that these individuals now depend on families, friends and other informal sources of funds to finance their businesses. Successive governments have come up with special rural biased programs, whose principal target is the overall development of rural enterprises with special consideration on micro and small scale enterprises and as well as alto empower rural dwellers. These programs range from Agricultural Development Projects (ADPs), the establishment of Agricultural Credit Banks to Better Life Programme for Rural Women among others. Unfortunately, most of the programs failed to achieve the desired result. This situation therefore led to the emergence of microfinance banks aimed at extending credits to micro-enterprises and encouraging entrepreneurship especially in semi-urban and rural areas [41].

The opportunity to possess capacity to access finance has been identified as a key element for small scale enterprises to succeed in a move to build productive capacity, compete, create jobs and contribute to poverty alleviation in developing countries. Small scale enterprises are seen as a risky venture, because of poor guarantees and lack of information about their ability to repay loans. Without access to finance, micro and small scale enterprises cannot acquire or absorb new technologies. Although, the banking sector is the largest and most important source of external financing for micro and small scale enterprises, however, it is believed to be under-serving the needs of this sector. Micro and small scale enterprises alternatively draw financing from a variety of sources [24].

In spite of considerable innovations in the microfinance services in the recent years, millions of people in Nigeria and the world at large still do not have access to basic financial services. The vast majority of those without access reside in developing countries, particularly in rural areas where it is more difficult and costly to extend these services. Although, progress has been made on how to supply rural financial services in a sustainable way, but no agreed body of best practice is yet available in designing the institutions and products the to meet the demand of this more challenging clientele [34].

Majority of the populace in the developing countries lack access to funds from financial institutions, either in form of overdraft, credit or long term loans, which has resulted to the low productivity in the economy. The situation will also result in low capital income which might further lead to poor savings and invariably leading to low capital accumulation which will eventually lead to low productivity (that is, the vicious circle of poverty). If the people of the developing countries have limited capacity to invest in capital, productivity is restricted, incomes are inhibited, domestic savings remain low and again, any increase in productivity is prevented [11, 18]. A lack of access to financial institutions also hinders the ability of entrepreneurs in developing countries to engage in new business ventures, inhibiting economic growth, and often, the sources and consequences of entrepreneurial activities are neither financially nor environmentally sustainable [37].

It would be observed that, despite the presumed developments in the Nigerian economy, the country is still largely being regarded as a developing country [12]. More so, its industrial growth is not quite impressive. Prior to the emergence of formal microfinance institutions, informal microfinance activities flourished all over the country. Traditionally, microfinance in Nigeria entails traditional informal practices such as local money lending, rotating credit and savings practices, credit from friends and relatives, poverty reduction programs, and so on [8].

The Central Bank of Nigeria Survey in 2001 indicated that the operations of formal microfinance institutions in Nigeria are relatively new, as most of them never registered after 1981. Before now, commercial banks traditionally lend to medium and large enterprises which are judged to be creditworthy. They avoided doing business with the poor and their micro enterprises because the associated cost and risks 
involved are considered to be relatively high [9].

Statement of the Problem, Research Questions and Objectives of the Study

It is amazing that the microfinance institutions that supposed to be a help and perhaps, expected to lend soft loan to entrepreneurs are now running business as if they are commercial banks. The ultimate question is, is microfinance institutions solution to poverty reduction in Nigeria? This study aims at examining rural financing as a panacea for poverty reduction in Ogun State, Nigeria. The objective of this study is examining the relationship between rural financing and poverty reduction in Nigeria with special reference to Ogun State. The hypothesis of this study is; there is no significant relationship between effective rural financing and poverty reduction in Nigeria.

\section{Review of Related Literature}

\subsection{Concepts of Poverty}

According to Encyclopedia Americana poverty can be seen from two different perspectives: First, moneylessness" which means both an insufficiency of cash and chronic inadequacy of resources of all types to satisfy basic human needs, such as, nutrition, rest, warmth and body care. Second, "powerlessness" meaning those who lack the opportunities and choices open to them and whose lives seem to them to be governed by forces and persons outside their control. That is, in positions of authority or by perceived 'evil forces' or 'hard luck'. Aku, Ibrahim and Bulus (1997) [20] perceived poverty from five dimensions of deprivation: personal and physical deprivation experienced from health, nutritional, literacy, educational disability and lack of self-confidence; economic deprivation drawn from lack of access to property, income, assets, factors of production and finance; social deprivation as a result of denial from full participation in social, political and economic activities; cultural deprivation in terms of lack of access to values, beliefs, knowledge, information and attitudes which deprives the people the control of their own destinies and political deprivation in term of lack of political voice to partake in decision making that affects their lives. Related to the definition of poverty is the measurement of poverty.

According to Foster, Greer and Thorbeck in 1984 [3] claimed that the most frequently used measurements are: the head court poverty index given by the percentage of the population that live in the households with a consumption per capita less than the poverty line; poverty gap index which reflects the depth of poverty by taking in to account how far the average poor person's income is from the poverty line; and the distributional sensitive measure of squared poverty gap defined as the means of the squared proportionate poverty gap which reflects the severity of poverty. Recent studies by United Nations Development Programme (UNDP) advocates the use of the Human Development Index (HDI). In the work of Ringim and Shuaib, HDI combine three (3) components in the measurement of poverty: (i) life expectancy at birth; (ii) education attainment and; improved standard of living determined by per capita income [36].

The first relates to survival-vulnerability to death at a relatively early age. The second relates to knowledge being excluded from the world of reading and communication. The third relates to a decent living standard in terms of overall economic provisioning. Poverty has various manifestations which include among others: lack of income and productive resources sufficient to ensure sustainable livelihood, hunger and malnutrition, ill health, limited or lack of access to education and other basic services, increased morbidity and mortality from illness, homelessness and inadequate, unsafe and degraded environment and social discrimination and exclusion [5]. It is also characterized by lack of participation in decision making in civil, social and cultural life [40, 39, 21] state that the causes of poverty include; structural causes that are more permanent and depend on a host of (exogenous) factors such as limited resources, lack of skill, location disadvantage and other factors that are inherent in the social and political set-up. The disables, orphans, landless farmers, household headed by females fall into this category; the transitional causes that are mainly due to structural adjustment reforms and changes in domestic economic policies that may result in price changes, increased unemployment and so on. Natural calamities such as wars, environmental degradation and so on also induce transitory poverty.

Discussing the consequences of poverty, the study [17] highlighted on three (3) major consequences: consequences for those affected, that is, for the people affected, poverty leads to physical and psychological misery caused inter-alia by inadequate nourishment, lack of medical care, a lack of basic and job related education and marginalisation in the labour market; consequences for the national economies of countries affected arising through the formation of slums in cities, a worsening of ecological problems particularly as a result of predatory exploitation in the agricultural sector and through the failure to use the available human resources; and consequences for the political and social development of the countries affected. That is, mass poverty tends to preserve or re-enforce the existing power structures and thus also the privileges of a minority of the population. In some cases, this involves corrupt elites. These privileged minorities in the population are not generally interested in structural changes for the benefit of the poor population. As a consequence, mass poverty tends to inhibit the development of democratic structure and a higher level of participation. As observed by the paper [21], with mass poverty there tend to be a general loss of confidence in the constituted authority thereby generating disrespect and rendering government policies ineffective; political apathy among contending forces; and social disillusion with respect to what the societal objectives are as well as people's responsibilities towards the attainment of these objectives.

A critical look at some of these causes and consequences discussed above provide some peculiarity with the poverty situation in Nigeria. The incidence of poverty in Nigeria 
increased from 28.1 per cent in 1980 to 88.0 per cent in the year 2012 [11]. This percentage represents in absolute term 86 million people out of an estimated population of about 116.4 million people. The poverty situation in Nigeria also depicts regional variation. For example, within these periods the poverty rate was higher in the northern agro-climatic zone at 40 per cent compared with the middle and southern zones at 38 per cent and 24 per cent respectively. Similarly, Nigeria's rank in the Human Development Index remained low $(0.470)$, being the 158 th among 182 countries [38]. The use of socio-economic indicators like per capita income, life expectancy at birth, access to health care services, access to safe water, access to education, access to sanitation facilities and electricity also depicts the extent of poverty in Nigeria.

The rate of poverty in Nigeria have not shown any remarkable reduction when viewed form these indicators and when compared with some countries in Africa. For instance, apart from the early 1980s when the nation's per capita income witnessed an increase the situations in the 1990s and early 2000 were pathetic. The life expectancy at birth (years) does not provide a better level of well-being in the country (47 years in 2007), more so when compared with those of countries like Mauritius and Tunisia that had 73 and 74 years respectively in 2007 [38].

To reduce poverty various schools of thought advocate a number of measures. For instance, the mercantilists laid emphasis on foreign trade which, according to them is an important vehicle for the promotion of economic growth and poverty reduction. The classical economists' (Adam Smith, David Ricardo, Thomas Malthus, Karl Marx, etc.) views on poverty reduction brought to the fore the social changes which were brought about by technological changes resulting from the industrial revolution that took place between 17501850. The early development economists of the 1940s and the 1950s advocate the theory of forced-drift industrialization via big push, balanced growth and labour transfer [20]. The study [16] advocates re-distribution of income. According to him, poverty can better be reduced if radical redistribution of income or land is allowed to take place in view of the interlocking power and self-interest of the rich and the bureaucracy in the handling of the nations' resources [20]. The World Bank $(1983 ; 1990 ; 1991)$ emphasizes on the need for stable macroeconomic policies and economic growth. According to the World Bank, sound fiscal and monetary policies will create the right atmosphere for private investment and thus promote productivity which in the longrun would lead to poverty reduction [16]. This approach is what is referred to as pro-poor growth approach to poverty reduction.

The 1980s to the 2000s had witness the introduction of new strategies and approaches to poverty reduction. Key among them are the basic needs, capabilities and entitlements approaches, participatory development, social capital, community self-help, good governance and human right approaches to poverty reduction [21]. In Nigeria, various efforts were made by the government, non-governmental organizations and individuals to reduce poverty in the country.

According to the study [20], poverty reduction measures implemented so far in Nigeria focuses more attention on economic growth, basic needs and rural development strategies. The economic growth approach focuses attention on rapid economic growth as measured by the rate of growth in real per capita (Gross Domestic Product) or per capita national income, price stability and declining unemployment among others, which are attained through proper harmonization of monetary and fiscal policies. The basic need approach focuses attention on the basic necessities of life such as food, health care, education, shelter, clothing, transport, water and sanitation, which could enable the poor live a decent life. The rural development approach focuses attention on the total emancipation and empowerment of the rural sector.

In furtherance to his discussions on the measures, the paper [20] grouped the strategies for poverty reduction in Nigeria into three eras - the pre-structural adjustment programme era, the structural adjustment programme era and the democratic era. In the pre-SAP era, the measures that were predominant were the Operation Feed the Nation, the River Basin Development Authorities, the Agricultural Development Programmes, the Agricultural Credit Guarantee Scheme, the Rural Electrification Scheme and the Green Revolution. In the SAP era the following poverty reduction measures were introduced; the Directorate for Food, Roads and Rural Infrastructures, the National Directorate of Employment, the Better Life Programme, the Peoples' Bank, the Community Banks, the Family Support Programme and the Family Economic Advancement Programme. The democratic era witnessed the introduction of the Poverty Alleviation Programme (PAP) designed to provide employment to 200,000 people all over the country. It was also aimed at inculcating and improving better attitudes towards a maintenance culture in highways, urban and rural roads and public buildings. By 2001 PAP was phased out and fused into the newly created National Poverty Eradication Programme (NAPEP) which was an integral part of the National Economic Empowerment and Development Strategy (NEEDS).

\subsection{Concepts of Rural Financing and Traditional Financial Institution}

Rural finance refers to the broad range of financial services, such as: savings, credit, payment transfers, leasing, insurance, etc provided by formal and informal financial services providers operating in rural financial markets. Rural finance addresses the financial needs of the rural population. Like other types of financial services, rural finance is a facilitator rather than a creator of economic opportunities. Where economic opportunities already exist, access to credit facilities can contribute to faster and more extensive adoption of improved technology which is consistent with raising the level of productivity and therefore the level of incomes [7].

Rural financing mechanism/traditional financial institutions includes cooperative societies, Rotating Savings 
and Credit Associations (ROSCAs), Accumulating Savings and Credit Associations (ASCAs), Fixed-funds associations, Savings clubs; the concept of esusu, concept of ajo, concept of aro. "Esusu", "Adashi", "Otataje", etc, which were popular practiced then aimed to provide funds for producers in the rural communities [5]. The informal rural finance arrangement operates under different names such as 'esusu' among the Yorubas in the Southwest, Nigeria, 'etoto' for the Igbos in the Eastern part of Nigeria and 'adashi' in the Northern part of the country. However, the common features of these groups are savings and credit components, informality of operations and low or no interest in relation to the commercial banking sector.

According to the study [19], micro-savings has existed in the developing world for many centuries. Rotating Saving and Credit Association (ROSCAs) are found in nearly every locale of the world. However, a very basic principle of ROSCAs is based on pooling resources with neighbours and friends to improve the situation of all members. The pool is distributed to one member of the ROSCA at a time until every each member has a chance to take from it. The system allows members to save earnings more quickly than they could individually. The ROSCAs are a form of microsavings, while experiments with micro credit have existed throughout the history. Micro credit however is a process of providing loans to the very poor with the purposes of poverty reduction and social change [32].

Jonathan Swift first introduced micro credit in the 18th century by establishing the Irish Loan Fund System, which provided small loans to poor farmers that lacked collateral [19]. At its peak, it annually serviced twenty per cent of all Irish households. Subsequently, Raiffeisen in 1972, developed the idea of a financial cooperative in Germany and cooperatives rapidly spread throughout Europe, and then to the rest of the world, in the mid 19th century. State owned development financial institutions, also known as farmer's cooperatives, started appearing in the mid-1950s and channeled loans to customers with lower-than-market interest rates. Such micro credit schemes were unsuccessful because customers interpreted the loans to be government handouts and were disinclined to pay them back [35]. Finally, in 1976, Muhammed Yunus pioneered the Grameen Bank [19], in which funds were provided to micro and small business owners, on low or single digit interest rate, for business operations.

\subsection{Empirical Review}

Evidence from the literature shows that adequate credit aids entrepreneurship performance. The result of such credit assistance to entrepreneurs is often seen as improved income, output, investment, employment and welfare of the entrepreneurs. Credit had positive impact on the business performance in Kenya, income and well-being of women in Uganda, also credit and savings had positive impact on the performance of entrepreneurs in Nigeria $[10,6,1,31,14$, 28]. Arising from the facts stated above, micro credit and its impact on the performance of entrepreneurs cannot be underestimated.

Microfinance is the form of financial development which primary aim is to alleviate poverty of the poor who are generally not served or are offered improper financial services $[2,26]$. They are established to fill the gap created by the formal financial sector by improving the socioeconomic condition of the poor and also their income generational activity. However, microfinance banks have not been able to adequately address the gap in terms of credit, savings and other financial services required by the small scale businesses. The study [22] further corroborated this by reporting that as laudable as the government programmes are towards financing of small enterprises, Micro-finance banks introduce stringent conditions day in, day out as they are not willing to release funds to micro-entrepreneurs.

\subsection{Linkages Between Rural Financing and Poverty Reduction}

Rural financing has many important roles to play in the development of Nigeria economy According to the study [13], these roles include:

Credit Delivery: This is perhaps one of the most important roles of rural financing as the loans extended are used to expand existing businesses and in some cases to start new ones. As such it is expected that agricultural output will increase with the increase in funding. The entrepreneurial capacity of the farmers will thus improve.

Boosting Small Scale Agro-Allied Enterprises: About 60 per cent of the poor people in the country live in rural areas and 80 percent of them are farmers and artisans. Rural financing has therefore been the main source of funding to these disadvantaged groups. Rural people are empowered through soft loans and services and hence small scale agroallied and microenterprises are developed.

Employment Generation: Agriculture and microenterprises contribute immensely to job creation, and are of particular interest to all. Extending credits and other services to many rural enterprises will enhance employment generation and promote entrepreneurship. The promotion of employment in rural areas through effective rural financing will covers the following areas; blacksmithing, gold-smiting, watch repairing, bicycle repairing, basket weaving, barbing, palm wine tapping, cloth weaving, dyeing, food selling, carpentry, brick-laying, pot-making, leather works and drumming. Although, these are found in urban areas as well but, these industries are more prominent in the rural areas. It has, therefore, been acknowledged that the rural setting is an arena for many industries, which could be developed to contribute significantly to the national economy, just as rural people are more frequently self-employed than urban people.

Improvement in Skill Acquisition: Improving the condition of women through the provision of skills acquisition and adult literacy is another role that effective rural financing will play. This is done through building capacities for wealth creation among enterprising poor people and promoting sustainable livelihood by strengthening rural responsive banking methodology and the introduction of simple cost- 
benefit analysis in the conduct of businesses in rural communities

\section{Methodology}

Survey method was adopted in the carrying out this study. Data were obtained through the use of questionnaires. The questions were done in simple and clear language to remove ambiguity. The response to each of the statements was on a 5 point Likert scale. The questionnaires were intended to generate responses that will assist the researcher to address the research problem, objectives, questions and hypothesis.

The theoretical population of the study consists of the entire small scale business operators in Ogun State. The population of this study cut across the small scale entrepreneurs in the state. Due to large number of small scale operators in Ogun State, the sample size was selected using stratified sampling and simple random sampling given the heterogeneous nature of the population. The sample size of 400 was obtained using Cochran (1997) formula, the calculation of the sample size

$$
\mathrm{n}=\frac{\mathrm{NZ} \mathrm{Z}^{2} \mathrm{pq}}{\mathrm{d}^{2}(\mathrm{~N}-1)+\mathrm{Z}^{2} \mathrm{pq}}
$$

Where:

$\mathrm{n}=$ Desired sample size, $\mathrm{N}=$ Total population $\mathrm{p}=0.5 \mathrm{q}=1-\mathrm{p}$ $\mathrm{d}=$ degree of accuracy or estimation $(=0.04)$

The population was divided into strata (four $\{4\}$ regions of Ogun State which comprised of Egba, Remo, Yewa and Ijebu) and simple random sampling method was used in selecting 100 respondents from the communities from each of the four (4) regions that make up Ogun State.

The questionnaire was basically the main instrument used to collect the data for this study. The questionnaire was divided into two sections. The first section contained the biodata of the respondents while the second section contained the questions relating to the main constructs of the study. Structured questionnaire was used for data collection in this study. The questionnaire which consists of a number of items in well-structured non-disguised manner was administered to and completed by the respondents. The decision to structure the questionnaire is predicated on the need to reduce variability in the meanings possessed by the questions as a way of ensuring comparability of responses

Ordinary least square regression method of analysis was adopted to show the causal relationship between rural financing and poverty reduction in Ogun State. In this study, poverty reduction/alleviation was made the dependent variable while rural financing was the explanatory variable. The model for analysis is;

$$
\begin{gathered}
\mathrm{PVT}=\mathrm{f}(\mathrm{RF}) \\
\mathrm{PVT}=\beta_{0}+\beta_{1} \mathrm{RF}+\mathrm{e}_{\mathrm{i}}
\end{gathered}
$$

Where;

PVT: Poverty Alleviation

RF: Rural Financing

$\beta_{0}$ and $\beta_{1}=$ are the regression coefficients to be determined. $\mathrm{e}_{\mathrm{i}}=$ the error term

Test of statistical adequacy, such as the adjusted Rsquare, t-statistic, F-statistic, Durbin-Watson were also carried out to assess the relative significance of the variables, the desirability and reliability of model estimation parameters.

A Priori Expectation: This explains the theoretical linkage on the signs and magnitudes of parameter of the specified functions. A priori expectations are determined by the principles of economic theory guiding the economic relationship among the variables being studied. The a priori expectation is that an increase rural financing will lead to alleviation in poverty rate vice versa. This implies that there is a positive relationship between rural financing and level of poverty reduction or alleviation.

\section{Data Analysis and Presentation}

The result of the model presented above indicates that the constant term rural financing is positive related to poverty reduction. This shows that an increase in the rural financing will lead to an increase in poverty alleviation or reduction and vice versa. The $\mathrm{T}$ calculated from the model indicates 7.972 and the $\mathrm{T}$ table show 1.645 this implies that the $\mathrm{T}$ calculated is greater than the $\mathrm{T}$ table, the implication of this is that the null hypothesis which states that there is no significant relationship between effective rural financing and poverty reduction in Nigeria is rejected.

Table 1. Descriptive Statistics.

\begin{tabular}{llll}
\hline & Mean & Std. Deviation & N \\
\hline Poverty Reduction & 3.0583 & .64587 & 400 \\
Rural financing & 3.4514 & .52081 & 400 \\
\hline
\end{tabular}

Table 2. Regression Variable Enter.

\begin{tabular}{llll}
\hline Model & Variables Entered & Variables Removed & Method \\
\hline 1 & Rural financing (a) & . & Enter \\
\hline
\end{tabular}

A All requested variables entered.

B Dependent Variable: Poverty Reduction. 
Table 3. ANOVA Data.

\begin{tabular}{lllllll}
\hline Model & & Sum of Squares & Df & Mean Square & F & Sig. \\
\hline \multirow{2}{*}{1} & Regression & 22.916 & 1 & 22.916 & 63.548 & $.000(\mathrm{a})$ \\
& Residual & 143.525 & 398 & .361 & \\
& Total & 166.441 & 399 & & & \\
\hline
\end{tabular}

A Predictors: (Constant), Rural financing.

B Dependent Variable: Poverty Reduction.

Table 4. Correlations.

\begin{tabular}{llll}
\hline & & Poverty Reduction & Rural financing \\
\hline \multirow{2}{*}{ Pearson Correlation } & Poverty Reduction & 1.000 & .371 \\
& Rural financing & .371 & 1.000 \\
Sig. (1-tailed) & Poverty Reduction &. & .000 \\
& Rural financing & .000 &. \\
$\mathrm{~N}$ & Poverty Reduction & 400 & 400 \\
& Rural financing & 400 & 400 \\
\hline
\end{tabular}

Variables Entered/Removed (b).

Table 5. Model Summary.

\begin{tabular}{|c|c|c|c|c|c|c|c|c|c|}
\hline \multirow[t]{2}{*}{ Model } & \multirow{2}{*}{$\begin{array}{l}\text { R } \\
\text { R Square Change } \\
\end{array}$} & \multirow{2}{*}{$\begin{array}{l}\text { R Square } \\
\text { F Change } \\
\end{array}$} & \multirow{2}{*}{$\begin{array}{l}\text { Adjusted } \\
\text { R Square } \\
\text { df1 }\end{array}$} & \multirow{2}{*}{$\begin{array}{l}\text { Std. Error of } \\
\text { the Estimate } \\
\text { df2 }\end{array}$} & \multicolumn{5}{|l|}{ Change Statistics } \\
\hline & & & & & Sig. F Change & R Square Change & F Change & df1 & df2 \\
\hline 1 & $.371(\mathrm{a})$ & .138 & .136 & .60051 & .138 & 63.548 & 1 & 398 & .000 \\
\hline
\end{tabular}

A Predictors: (Constant), Rural financing.

Table 6. Coefficients.

\begin{tabular}{|c|c|c|c|c|c|c|c|c|c|c|c|c|}
\hline \multirow{2}{*}{ Model } & \multicolumn{2}{|c|}{$\begin{array}{l}\text { Unstandardized } \\
\text { Coefficients }\end{array}$} & \multirow{2}{*}{$\begin{array}{l}\text { Standardized } \\
\text { Coefficients } \\
\text { Beta }\end{array}$} & \multirow{2}{*}{$\begin{array}{l}\text { T } \\
\text { Lower } \\
\text { Bound }\end{array}$} & \multirow{2}{*}{$\begin{array}{l}\text { Sig. } \\
\text { Upper } \\
\text { Bound }\end{array}$} & \multicolumn{2}{|c|}{$\begin{array}{l}\text { 95\% Confidence } \\
\text { Interval for B }\end{array}$} & \multicolumn{2}{|c|}{ Correlations } & \multicolumn{3}{|c|}{$\begin{array}{l}\text { Collinearity } \\
\text { Statistics }\end{array}$} \\
\hline & B & $\begin{array}{l}\text { Std. } \\
\text { Error }\end{array}$ & & & & $\begin{array}{l}\text { Zero- } \\
\text { order }\end{array}$ & Partial & Part & Tolerance & VIF & B & $\begin{array}{l}\text { Std. } \\
\text { Error }\end{array}$ \\
\hline 1 (Constant) & 1.470 & .201 & & 7.297 & .000 & 1.074 & 1.866 & & & & & \\
\hline Rural financing & .460 & .058 & .371 & 7.972 & .000 & .347 & .574 & .371 & .371 & .371 & 1.000 & 1.000 \\
\hline
\end{tabular}

A Dependent Variable: Poverty Reduction.

Table 7. Coefficient Correlations (a).

\begin{tabular}{llll}
\hline Model & Rural financing & & \\
\hline \multirow{2}{*}{1} & Correlations & Rural financing & 1.000 \\
& Covariances & Rural financing & .003 \\
\hline
\end{tabular}

A Dependent Variable: Poverty Reduction.

Table 8. Collinearity Diagnostics (a).

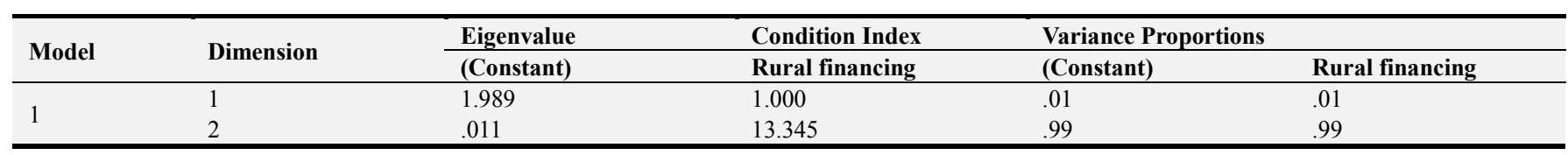

A Dependent Variable: Poverty Reduction.

The Durbin Waston statistics is used to test for the presence of first order serial correlation. It measures the linear association between adjacent residual from the regression model. The calculated DW statistics is 1.615 . The descriptive statistics show that the mean and standard deviation for poverty reduction is 3.0583 and $64.59 \%$ while the mean and standard deviation for rural financing is 3.4514 and $52.08 \%$ respectively. The test of significance shows that an increase or decreases in rural financing do have significant effect on poverty reduction or alleviation.

The standard error for the model is 0.058 , which therefore implies that the model is statistically significant. This indicates that the increase or decrease in the explanatory variable (rural financing) will have a significant effect on poverty reduction or alleviation. The F-statistics is used to test for stability in the regression parameter coefficient. From the table $\mathrm{F}$ statistics at 0.05 is 2.45 , while the calculated $F^{*}$ is 63.548 , it shows that the overall model is statistically significant.

\subsection{Discussion of Findings}

Evidence from the above show that adequate facilities credit aid entrepreneurial performance and reduces poverty. This was 
supported by Casmir (2014); Akingunola, Adekunle, Adegbesan, and Aninkan (2013); Abdulkadir, Umar, Bashir and Ibrahim (2012); Ojo (2009); Ekpe, Mat and Razak (2010); Nwibo and Okorie (2013). The result of such credit assistance to entrepreneurs is often seen as improved income, output, investment, employment and welfare of the entrepreneurs (Ekpe, Mat and Razak, 2010; Nwibo \& Okorie, 2013; Casmir, 2014; Akingunola, Adekunle, Adegbesan, \& Aninkan, 2013). Credit had positive impact on the business performance in Ogun State, Nigeria, increases income and well-being of SMEs operators in the state.

\subsection{Conclusion}

The study concludes that credit and savings has a positive impact on the performance of entrepreneurs in Ogun State in particular and Nigeria as a whole. Arising from the facts stated above, micro credit and its impact on the performance of entrepreneurs cannot be underestimated. Needless to say that, the issue of rural financing is important since it will directly impact the living standard of the populace. So, there is need for government at all level to priority the formulation and implementation of policy that will provide various financing options for rural dwellers. This will in turn reduce poverty level which has become endemic to our rural community and result to even development of the society at large.

\subsection{Recommendations}

From the analysis done and conclusion drawn, the following are hereby recommended:

i. Establish a credit information exchange mechanism that would track all borrowings and repayments in rural communities.

ii. Government at all levels should revitalize their social mobilization networks to nurture viable groups/associations of tradesmen, artisans, producers and workers among others, to provide effective group guarantee for microfinance lending and as well as promote the savings culture among the among the rural dwellers.

iii. The Central Bank of Nigeria need to re-introduce rural banking for all banks and require every bank to open one rural branch for every five urban branches.

iv. There is also a need to review the curricula in the Nigerian educational system to emphasize selfemployment and entrepreneurship and tone down wage expectations of graduates after school. This would go a long way to increase the supply of entrepreneurs across the country and produce the type of employees with the temperament for microfinance industry.

\section{References}

[1] Abdulkadir, F. I., Umar, S., Bashir, G. I. \& Ibrahim, S. H. (2012). The impact of micro-finance banks on women entrepreneurial development in metropolis: microeconomics and macroeconomics Scientific and Academic Publishing; 1 (3): 28-38.
[2] Acha, I. A. (2012). Microfinance Banking in Nigeria: Problems and Prospects. International Journal of Finance and Accounting; 1 (5): 106-111.

[3] Adekoya, O. A. (2014). Analysis of farm households poverty status in Ogun States, Nigeria. Asian Economic and Financial Review, 2014, 4 (3): 325-340.

[4] Adeyemi, S. L.; Ijaiya, G. T. \& Raheem, U. A. (2009). Determinants of poverty in sub-saharan Africa. African Research Review, an International Multi-Disciplinary Journal, 3 (2): 162-177.

[5] Akinboyo, O. L. (2007). Microfinance banks: unlocking the potentials of micro-business activities of the Nigerian rural economy. CBN Bullion 31 (1): 39-51.

[6] Akingunola, R. O., Adekunle, O. A., Adegbesan, K. J. \& Aninkan, O. O. (2013). Microfinance banks and entrepreneurship development in Nigeria: A case of Ogun State. European Journal of Business and Management; 5 (28).

[7] Akinlo, A. E. (2014). Policy choices and challenges in expanding access to finance for growth in rural Nigeria. European Journal of Sustainable Development, 3 (1): 135144.

[8] Alani, G. O. \& Sani, J. (2014). Effects of microfinance banks on the rural dwellers in Kogi State, Nigeria. International Journal of Public Administration and Management Research, 2 (2): 66-79.

[9] Anyanwu. C. M. (2004). Microfinance institutions in Nigeria: Policy, practice and potentials. Paper presented at the G24 workshop on "constraints to growth in sub Saharan Africa" Pretoria. South Africa.

[10] Casmir, O. C. (2014). Impact of micro credit on the performance of women entrepreneurs in Delta State. International Journal of Empirical Finance (2) 1: 45-51.

[11] Central Bank of Nigeria (2013). Financial inclusion in Nigeria: Issues and challenges. Occasional Paper No. 45, Edited by Kama, U. \& Adigun, M.

[12] Chete, L. N., Adeoti, J. O., Adeyinka, F. M. \& Ogundele, O. (2014). Industrial development and growth in Nigeria: Lessons and challenges - Working Paper No. 8. Retrieved from https://www.brookings.edu/wpcontent/uploads/2016/07/L2C_WP8_Chete-et-al-1.pdf.

[13] Egbetunde, T. (2012). Bank credits and rural development in Nigeria (1982-2009). International Journal of Finance and Accounting, 1 (3): 45-52.

[14] Ekpe, I., Mat, N. B. \& Razak, R. C. (2010). The Effect of Microfinance Factors on Women entrepreneurs' performance in Nigeria: A Conceptual framework. International Journal of Business and Social Science 1 (2).

[15] Encyclopedia Americana (1989).

[16] Faroh, A. (2015). Economic growth and poverty reduction in Sierra Leone. International Journal of Economics, Commerce and Management; Vol. III, Issue 2, Feb.

[17] Gangas, S. (2017). Relationship between economic growth and poverty reduction in Nigeria. Pyrex Journal of Business and Finance Management Research; Vol 3 (2) pp. 34-56, February. 
[18] Gichuki, J. A. W.; Njeru, A. \& Tirimba, O. I. (2014). Challenges Facing Micro and Small enterprises in accessing credit facilities in Kangemi Harambee Market in Nairobi City, Kenya. International Journal of Scientific and Research Publications, 4 (12).

[19] Idowu, A. \& Salami, A. O. (2011). Impact of microfinance bank on standard of living of hairdresser in Ogbomoso North Local Government of Oyo State, Nigeria. International Business Management - Medwell Journal; 5 (1): 27-32.

[20] Ijaiya, G. T.; Ijaiya, M. A.; Bello, R. A. \& Ajayi, M. A. (2011). Economic growth and poverty reduction in Nigeria. International Journal of Business and Social Science, 2 (15): 147-154.

[21] Ijaiya, M. A.; Sakariyau, O. B.; Dauda, C. K.; Paiko, I. I. \& Zubairu, U. M. (2012). Social capital and poverty reduction in Nigeria: A case study of Minna Metropolis. International Journal of Business and Social Science, 3 (12): 229-236.

[22] Kasali, T. A. (2006). Financing small and medium scale industries for economic recovery. Journal of Management and Enterprise Development; 3 (2).

[23] Kolawole, O. D. \& Torimiro, D. O. (2005). Participatory rural entrepreneurship development for grassroots transformation: A factor analysis. Journal of Human Ecology, 18 (3): 193-198.

[24] Mwangi, M.; George, G. E.; Mindila, R.; Nyakwara, S.; Ongeri, J. \& Okeyo, H. N. (2013). An evaluation of financing and development of small and medium enterprises in Mombasa, Kenya. European Journal of Business and Management, 5 (14).

[25] National Bureau for Statistics (2012). Nigeria Poverty Profile 2010. Working Paper.

[26] Nudamatiya, A. B.; Giroh, D. Y. \& Shehu, J. F. (2010). Analysis of micro-finance impact on poverty reduction in Adamawa State, Nigeria. Journal of Agriculture and Social Sciences, 6 (4): 91-95.

[27] Nwanyanwu, O. J. (2011). Micro Finance in Nigeria: Problems and Prospects. Africa Research Review: An International Multi-Disciplinary Journal, Ethiopia; 5 (2), Serial No. 19, April, 87-103.

[28] Nwibo, S. U. \& Okorie, A. (2013). Constraints to entrepreneurship and investment decisions among agribusiness investors in Southeast, Nigeria. International Journal of Small Business and Entrepreneurship Research, 1 (4): $30-42$.

[29] Odularu, G. O. (2007). Crude oil and the Nigerian economic performance: Oil and gas business. Retrieved from http://www.ogbus.ru/eng/authors/odularo/odularo_1.pdf.

[30] Ogujiuba, K. (2014). Poverty incidence and reduction strategies in Nigeria: Challenges of meeting 2015 MDG Targets. Journal of Economics, 5 (2): 201-217.
[31] Ojo, O. (2009). Impact of microfinance on entrepreneurial development: The case of Nigeria. A paper presented at The International Conference on Economics and Administration, Faculty of Administration and Business, University of Bucharest, Romania ICEA-FAA Bucharest.

[32] Okafor, I. G. (2014). Impact of microfinance banks activities on poverty alleviation in Nigeria: 1993 - 2013. Ph. D. Unpublished Thesis. Retrieved from http://www.unn.edu.ng/publications/files/ OKAFOR\%20Ph.D\%20RESERACH.pdf.

[33] Olaitan, M. A. (2006). Finance for the SMEs- Nigeria's Agricultural Credit Guarantee Scheme Fund.

[34] Organisation for Economic Co-operation and Development (2004). Promoting entrepreneurship and innovative SME's in a global economy: Towards a more responsible and inclusive globalisation. 2nd OECD Conference of Ministers Responsible for Small and Medium-Sized Enterprises (SMEs) - Istanbul, Turkey 3-5 June. Retrieved from http://www.oecd.org/cfe/smes/31919278.pdf.

[35] Prinz, M. (2012). Agricultural, cattle breeding and fishing Cooperativism and Associationism in Europe and Latin America, XIXth and XXth centuries: a compared perspective. Paper delivered to the XIII IEHA Congress Buenos Aires, July. Retrieved from http://citeseerx.ist.psu.edu/viewdoc/download?doi=10.1.1.538 $.4312 \&$ rep $=$ rep $1 \&$ type $=$ pdf.

[36] Ringim, K. J. \& Shuaib, S. N. (2017). Influence of Social Capital on Consumption Per-Capita income and poverty alleviation in tertiary institution cooperative thrift and credit society. Mediterranean Journal of Social Sciences, 8 (3).

[37] Sjauw-Koen-Fa, A. \& Vereijken, I. (2005). Access to financial services in developing countries - The Rabobank view. Economic Research Department of Rabobank, Nederland.

[38] UNDP (2016). Human Development for Everyone: Briefing note for countries on the 2016 Human Development Report Nigeria. Retrieved from http://hdr.undp.org/sites/all/themes/ hdr_theme/country-notes/es/NGA.pdf.

[39] United Nations (2001). Substantive issues arising in the implementation of the International Covenant on Economic, Social and Cultural Rights. Published by Committee on Economic, Social and Cultural Rights, Economic and Social Council, May 10.

[40] World Economic Forum (2013). The future role of civil society. World Scenario Series; published by World Economic Forum, in collaboration with KPMG International, January.

[41] Yusuf, S. A.; Amao, J. O. \& Olawale, O. T. (2014). Effects of microcredit on small scale enterprises in Osun State, Nigeria. American International Journal of Contemporary Research, 4 (6). 